\title{
Interaction of rose bengal with mung bean aspartate transcarbamylase
}

\author{
P. V. PRASAD* and N. APPAJI RAO \\ Department of Biochemistry, Indian Institute of Science, Bangalore 560 012, India \\ * Present address: Department of Biochemistry, Scripps Clinic and Research Foundation, La \\ Jolla, California 92037, USA
}

MS received 30 April 1984

\begin{abstract}
The fluorescein dye, rose bengal in the dark: (i) inhibited the activity of mung bean aspartate transcarbamylase (EC 2.1.3.2) in a non-competitive manner, when aspartate was the varied substrate; (ii) induced a lag in the time course of reaction and this hysteresis was abolished upon preincubation with carbamyl phosphate; and (iii) converted the multiple bands observed on polyacrylamide gel electrophoresis of enzyme into a single band. The binding of the dye to the enzyme induced a red shift in the visible spectrum of dye suggesting that it was probably interacting at a hydrophobic region in the enzyme. The dye, in the presence of light, inactivated the enzyme and the inactivation was not dependent on $\mathrm{pH}$. All the effects of the dye could be reversed by UMP, an allosteric inhibitor of the enzyme. The loss of enzyme activity on photoinactivation and the partial protection afforded by Nphosphonoacetyl-L-aspartate, a transition state analog and carbamyl phosphate plus succinate, a competitive inhibitor for aspartate, as well as the reversal of the dye difference spectrum by N-phosphonoacetyl-L-aspartate suggested that in the mung bean aspartate transcarbamylase, unlike in the case of Escherichia coli enzyme, the active and allosteric sites may be located close to each other.
\end{abstract}

Keywords. Mung bean; aspartate transcarbamylase; interactions; active site; rose bengal; allosteric

\section{Introduction}

Dyes have been extensively used to probe the structure-function relationships of proteins (Glazer, 1970; Thompson et al., 1975; Thompson and Stellwagen, 1976). The studies on the interaction of tetraiodofluorescein at the CTP and ATP binding site of Escherchia coli aspartate transcarbamylase (EC 2.1.3.2) provided valuable information on the regulatory mechanism of this enzyme (Jacobsberg et al., 1975). Rose Bengal (tetrachloro-tetraiodo fluorescein) was used to study the nature of nucleotide binding sites in some enzymes (Brand et al., 1967; Bond et al., 1970; Rippa et al., 1970). It was also used to photoinactivate and identify the amino acid residues at the binding sites of some enzymes (Westhead, 1965; Kamogawa and Fukui, 1975; Coulson and Yonetani, 1972). Although UMP was the most potent allosteric effector of mung bean aspartate transcarbamylase, the enzyme was also inhibited by UDP and UTP (Savithri et al., 1978a). In an earlier communication we have reported a modified procedure for the purification of the enzyme and have shown that the enzyme is probably regulated by

Abbreviations used: PALA, N-Phosphonoacetyl-L-aspartate; PAGE, polyacrylamide gel electrophoresis. 
slow association-dissociation between polymeric forms which respond differently to substrate(s) and allosteric effectors (Prasad and Appaji Rao, 1984). The present paper describes the interaction of rose bengal at the UMP binding region of mung bean aspartate transcarbamylase.

\section{Materials and methods}

\section{Materials}

All the chemicals except rose bengal and N-phosphonoacetyl-L-aspartate (PALA) were obtained from Sigma Chemical Co., St. Louis, Missouri, USA. Rose bengal was obtained from Eastman Kodak Co., Rochester, New York, USA. PALA was a kind gift from Dr. Leonard Kedda, Drug Synthesis and Chemistry Branch, National Cancer Institute, Bethesda, Maryland, USA.

\section{Methods}

Aspartate transcarbamylase was purified as described earlier (Prasad, 1983; Prasad and Appaji Rao, 1984). The enzyme was assayed by a colorimetric procedure (Prescott and Jones, 1969). The standard assay mixture $(1 \mathrm{ml})$ contained $0.1 \mathrm{M}$ Tris-acetate buffer, $\mathrm{pH}$ 8.0 ; carbamyl phosphate, $5 \mathrm{mM}$; L-aspartate, $10 \mathrm{mM}$ and an appropriate amount of the enzyme. The reaction was started by the addition of L-aspartate and terminated after $10 \mathrm{~min}$ of incubation at $25^{\circ} \mathrm{C}$ by the addition of $0.05 \mathrm{ml}$ of $20 \%$ perchloric acid. The amount of N-carbamyl-L-aspartate formed was estimated by the method of Prescott and Jones (1969). When rose bengal was included in the assay mixture, all the incubations and the reaction were conducted in the dark to prevent photoinactivation of the enzyme by the dye. One unit of enzyme activity was defined as the amount of enzyme that catalyzed the formation of $1 \mu \mathrm{mol}$ of $\mathrm{N}$-carbamyl-L-aspartic acid per min at $25^{\circ} \mathrm{C}$ and $\mathrm{pH} 8 \cdot 0$. Protein was determined by the method of Lowry et al. (1951) with bovine serum albumin as the standard.

Rose bengal was purified by the method of Hoffee et al. (1967). Photooxidation of the enzyme in the presence of rose bengal was carried out in the electrode chamber of a Gilson KIC-oxygraph. The reaction vessel was surrounded by an outer jacket through which water was circulated at a constant temperature $\left(26^{\circ} \mathrm{C}\right)$. The reaction mixture $(0.7 \mathrm{ml})$ contained $20 \mathrm{mM}$ Tris-acetate buffer, $\mathrm{pH} 8 \cdot 0$, rose bengal at the indicated concentrations and an appropriate amount of the enzyme. Photooxidation was initiated by switching on a $250 \mathrm{~W}$ Tungsten lamp placed at a distance of $6 \mathrm{~cm}$ from the reaction vessel. At various time intervals, aliquots $(0.1 \mathrm{ml})$ were withdrawn and mixed with $0.8 \mathrm{ml}$ of $0 \cdot 1 \mathrm{M}$ Tris-acetate buffer, $\mathrm{pH} \quad 8.0$ containing $2.5 \mathrm{mM}$ carbamyl phosphate. The aliquots were stored in the dark at $4{ }^{\circ} \mathrm{C}$ and assayed together at the end of the experiment for the residual enzyme activity by the addition of $10 \mathrm{mM}$ Laspartate. The activity at zero time was taken as 100 and the per cent residual activity at different periods of inactivation was calculated. The results were plotted in the form of a semi-logarithemic plot of $\ln$ (per cent residual activity) versus time. The slopes of these lines, calculated by least square analysis gave the pseudo first order rate constant $\left(k_{\text {app }}\right)$ of inactivation at various concentrations of rose bengal. 
Absorption spectra were recorded at $25^{\circ} \mathrm{C}$ in a Gary 219 recording spectrophotometer using $0.3 \mathrm{ml}$ quartz cells of $1 \mathrm{~cm}$ pathlength.

Polyacrylamide disc gel electrophoresis (PAGE) was conducted according to the method of Davis (1964) in $0.1 \mathrm{mM}$ Tris-glycine buffer, $\mathrm{pH} 8.6$ containing $15 \mu \mathrm{M}$ rose bengal. The enzyme $(40 \mu \mathrm{g})$ was preincubated with $15 \mu \mathrm{M}$ rose bengal for $10 \mathrm{~min}$ in the dark and applied onto $7.5 \%$ gels. Electrophoresis was conducted in the dark at $4{ }^{\circ} \mathrm{C}$ using a current of $2.5 \mathrm{~mA}$ per tube. Electrophoresis was terminated when the marker dye migrated to a distance of about $0.5 \mathrm{~cm}$ from the bottom of the gel. The gels were stained for protein by Coomassie Brilliant Blue R 250 and destained with methanol:acetic acid: water (43:7:50, v/v). Activity staining was carried out according to a slightly modified procedure of Grayson and Yon (1978). The gels were washed thoroughly with cold $0.1 \mathrm{M}$ Tris-acetate buffer, $\mathrm{pH} 8.0$ and incubated overnight in the same buffer containing $5 \mathrm{mM}$ carbamyl phosphate, $10 \mathrm{mM}$ L-aspartate and $10 \mathrm{mM}$ $\mathrm{CaCl}_{2}$ at $4{ }^{\circ} \mathrm{C}$. Aspartate transcarbamylase activity was revealed as a white opalescent precipitate of calcium phosphate.

\section{Results}

Inhibition of mung bean aspartate transcarbamylase activity by rose bengal

The activity of the enzyme was inhibited by rose bengal in the dark at $\mathrm{pH} 8.0$ in a sigmoidal fashion (figure 1) with a $n_{H}$ value of 3.2 (figure 1, inset). From the Hill plot, a $\mathrm{I}_{0.5}^{k} 5.6 \mu \mathrm{M}$ was calculated by a least squares analysis of the data.

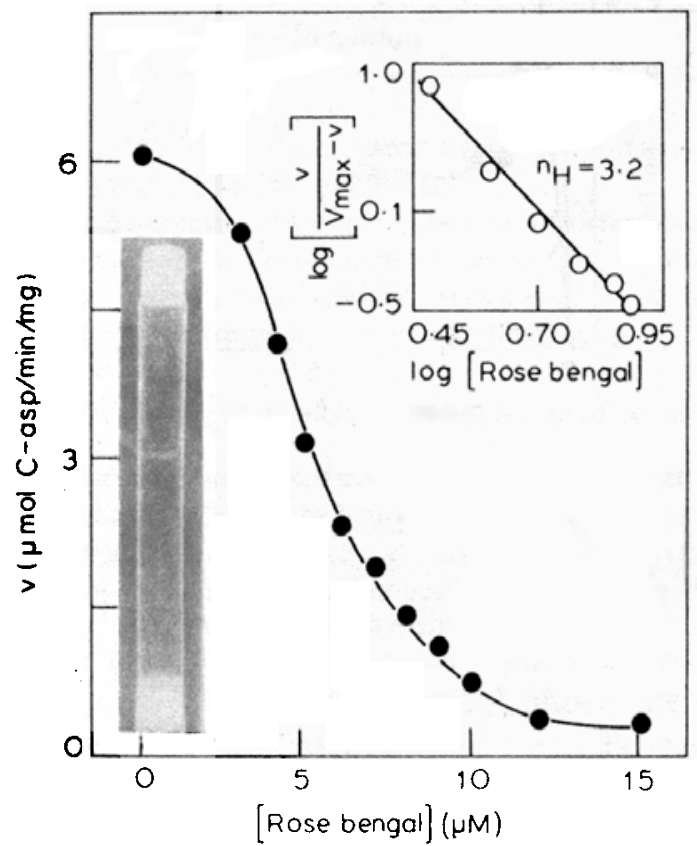

Figure 1. Inhibition of the activity of the enzyme by rose bengal. Inset: Hill plot. The enzyme $(2.6 \mu \mathrm{g})$ was preincubated in the dark with various concentrations of rose bengal in the assay buffer for $10 \mathrm{~min}$ at $25^{\circ} \mathrm{C}$ followed by a second preincubation with $5 \mathrm{mM}$ carbamyl phosphate. The enzyme $(40 \mu \mathrm{g})$ was preincubated in the dark with rose bengal and subjected to PAGE and the enzyme band was located by activity staining. 


\section{Effect of rose bengal on carbamyl phosphate saturation of the enzyme}

Carbamyl phosphate saturation of the enzyme was determined at $\mathrm{pH} 8.0$ in the absence and in the presence of $5 \mu \mathrm{M}$ rose bengal. The saturation of the enzyme in the absence of rose bengal was hyperbolic (figure 2). Maximum velocity of the reaction was attained at a carbamyl phosphate concentration of about $0.25 \mathrm{mM}$ and increasing the substrate concentration beyond $0.25 \mathrm{mM}$ had no effect on the velocity of the reaction. On the other hand, the enzyme showed a complex pattern of carbamyl phosphate saturation with a maximum and a plateau region in the presence of rose bengal. This pattern was similar to the carbamyl phosphate saturation pattern of a partially purified enzyme preparation when the reaction was started by the addition of the enzyme (Prasad and Appaji Rao, 1984).

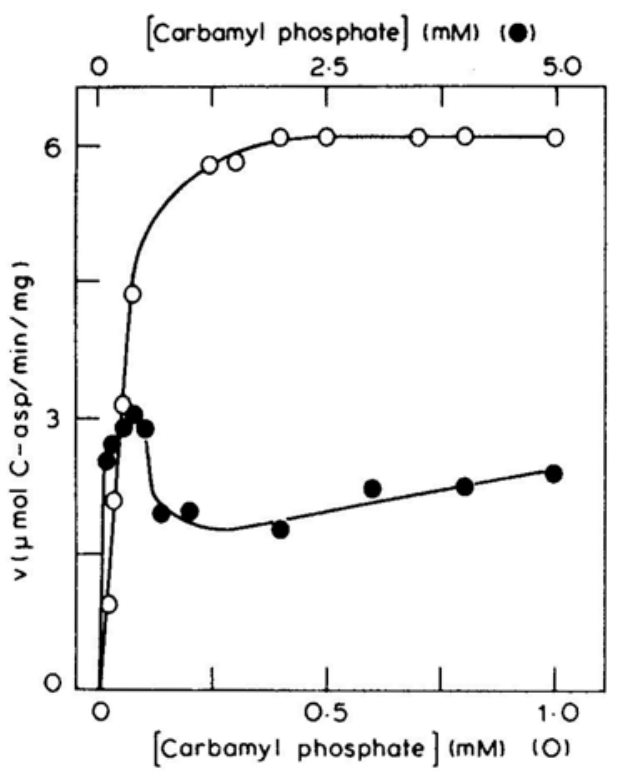

Figure 2. Effect of rose bengal on carbamyl phosphate saturation of the enzyme.

The enzyme $(1.9 \mu \mathrm{g})$ was preincubated with varying concentrations of carbamyl phosphate for $10 \mathrm{~min}(\mathrm{O})$ or with $5 \mu \mathrm{M}$ rose bengal for $10 \mathrm{~min}$ followed by varying concentrations of carbamyl phosphate (I ).The reaction was started by the addition of $10 \mathrm{mM}$ L-aspartate and the activity of the enzyme was determined as described.

\section{Effect of rose bengal on L-aspartate saturation of the enzyme}

Rose bengal acted as a noncompetitive inhibitor of the enzyme when L-aspartate was the varied substrate (figure 3). A replot of the slopes and intercepts (figure 3, inset) of the Lineweaver-Burk plots at different concentrations of rose bengal indicated that the dye was a linear noncompetitive inhibitor of the enzyme (Cleland, 1970). From the slope replot, a $K_{i}$ value of $9 \mu \mathrm{M}$ was calculated for the dye. 


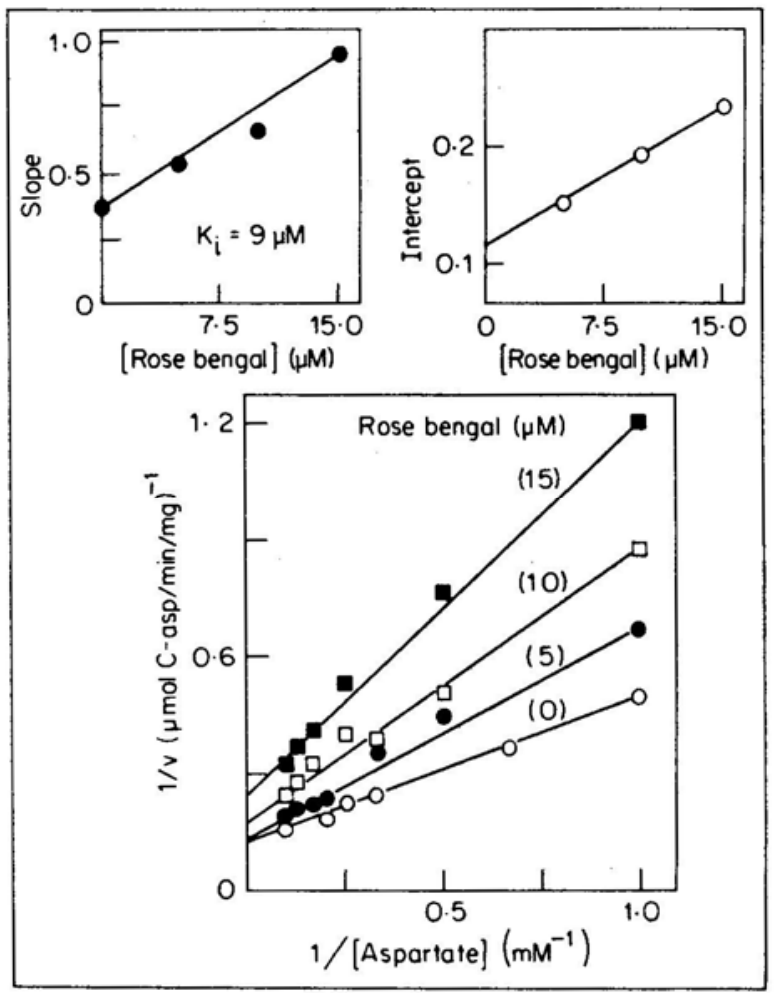

Figure 3. Lineweaver-Burk plots for L-aspartate saturation of the enzyme in the presence of $0(\mathrm{O}), 5(\mathrm{I}), 10(\square)$ and $15 \mu \mathrm{M}(\mathbf{\square})$ rose bengal.

The enzyme $(1.7 \mu \mathrm{g})$ was preincubated in the dark with different fixed concentrations of rose bengal for $10 \mathrm{~min}$ in the assay buffer followed by a second preincubation with $5 \mathrm{mM}$ carbamyl phosphate. Reaction was started by adding varying concentrations of L-aspartate. Inset: Replot of the slopes and intercepts of Lineweaver-Burk plots.

\section{Time course of the enzymatic reaction in the presence of rose bengal}

The kinetic effects of UMP and rose bengal was followed by monitoring the progress of the enzymatic reaction with time in the presence of rose bengal. The enzyme showed a linear progress curve in the absence of rose bengal (figure 4). When it was preincubated with $5 \mu \mathrm{M}$ rose bengal and the reaction started by the addition of carbamyl phosphate plus L-aspartate, there was a lag phase in the time course of the reaction (figure 4). Preincubation with rose bengal followed by carbamyl phosphate (figure 4) abolished the rose bengal induced hysteretic behaviour. These results were similar to those observed with UMP (Prasad and Appaji Rao, 1984).

\section{Photoinactivation of the enzyme in the presence of rose bengal}

The photoinactivation of the enzyme in the presence of varying concentrations of rose bengal followed pseudo first order kinetics as indicated by the linear semilogarithemic plots (figure 5). Pseudo first order kinetics were observed until the enzyme was almost 


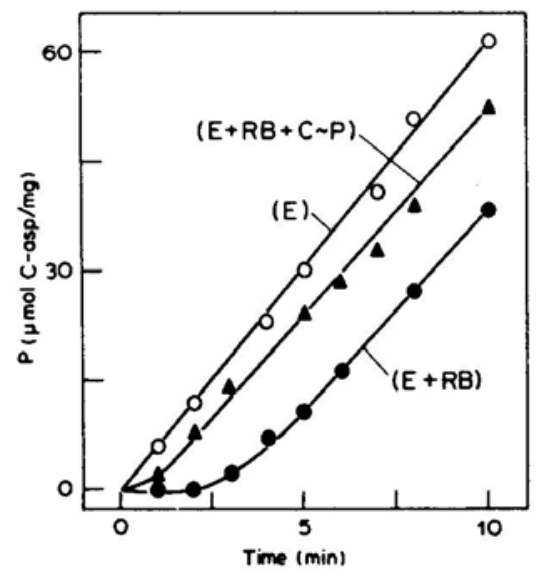

Figure 4. Time course of the reaction after preincubating the enzyme with rose bengal(I ), rose bengal followed by carbamyl phosphate $(\boldsymbol{\Delta})$ or with no preincubation $(\mathrm{O})$.

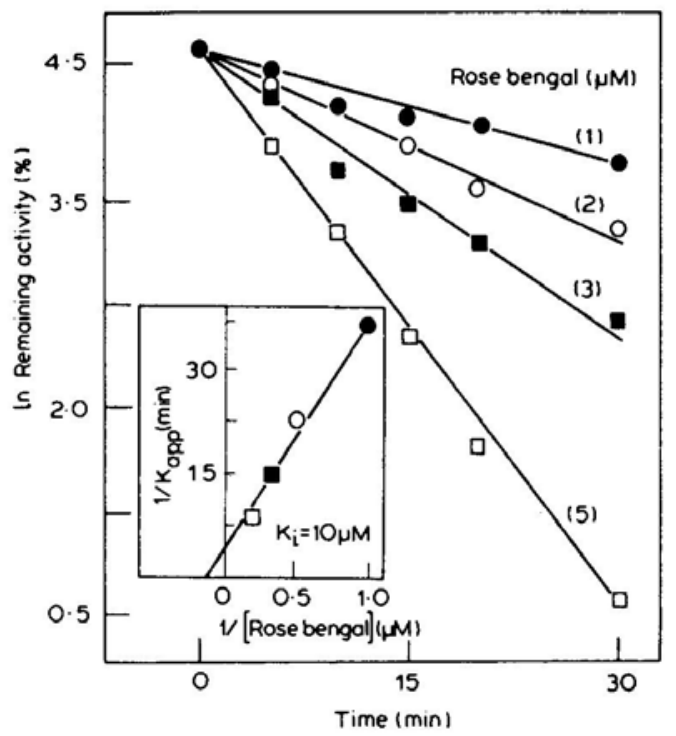

Figure 5. Photoinactivation of the enzyme in the presence of rose bengal. Semilogarithimic plots of In (\% residual activity) vs time for the photo-inactivation of the enzyme in the presence of $1(\mathrm{l}), 2(\mathrm{O}), 3(\square)$ and $5 \mu \mathrm{M}(\square)$ rose bengal. The enzyme $(10 \mu \mathrm{g})$ was subjected to photooxidation in the presence of rose bengal as described under 'Methods'. Inset: Determination of the $K_{i}$ for rose bengal.

completely inactivated. When $\left(K_{\mathrm{app}}\right)^{-1}$ was plotted against [rose bengal] ${ }^{-1}$, a linear relationship (correlation coefficient $=0.98$ ) was obtained (inset, figure 5) indicating that photooxidation by rose bengal followed saturation kinetics. From a least square analysis of the data given in the figure 5 , a $K_{i}$ value of $10 \mu \mathrm{M}$ was obtained for rose bengal from the intercept on the $\mathrm{X}$-axis which is in very good agreement with the $K_{i}$ value of $9 \mu \mathrm{M}$ obtained from the inhibition studies (figure 3 ). 
Protection against photoinactivation in the presence of rose bengal by biospecific ligands

In order to ascertain whether rose bengal was interacting at a specific site on the enzyme, the ability of biospecific ligands to protect the enzyme against photoinactivation of the enzyme by rose bengal was studied. The ability of various ligands to protect the enzyme is shown in figure 6 in the form of pseudo first order plots. Carbamyl phosphate $(2.5 \mathrm{mM})$ and L-aspartate $(10 \mathrm{mM})$ did not protect the enzyme against inactivation. The concentrations of these ligands were much higher than their $K_{m}$ values $(0.25 \mathrm{mM}$ for carbamyl phosphate and $0.5 \mathrm{mM}$ for L-aspartate). However, when succinate, a competitive inhibitor with respect to L-aspartate (Savithri et al., $1978 \mathrm{~b})$ and carbamyl phosphate $(2.5 \mathrm{mM})$ were present together, the enzyme was almost completely protected against photoinactivation. Similarly, the transition state analog, PALA $(25 \mu \mathrm{M})$ which has the structural features of both the substrates (Collins and Stark, 1971) or the allosteric effector, UMP (1 mM) also protected the enzyme against inactivation suggesting that blocking of either the allosteric site or both the substrate sites protected the enzyme against photoinactivation in the presence of rose bengal.

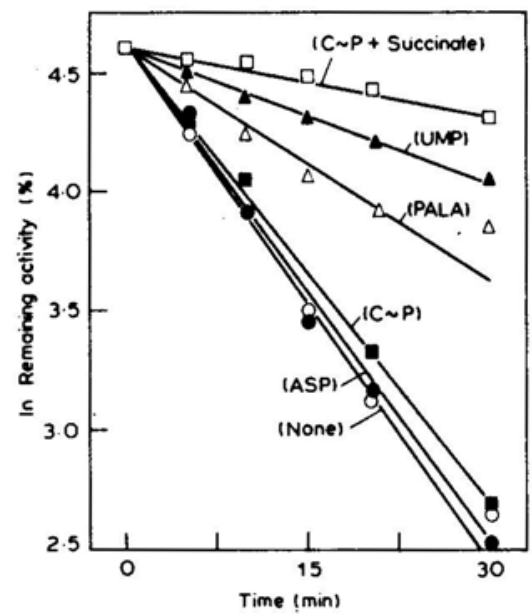

Figure 6. Protection by substrates and effectors against photoinactivation of the enzyme by rose bengal.

The enzyme $(10 \mu \mathrm{g})$ was subjected to photoinactivation in the presence of $3 \mu \mathrm{M}$ rose bengal as described. The inactivation mixture also contained carbamyl phosphate $(2.5 \mathrm{mM})$ or Laspartate $(10 \mathrm{mM})$ or carbamyl phosphate $(2.5 \mathrm{mM})$ plus succinate $(10 \mathrm{mM})$ or PALA $(25 \mu \mathrm{M})$ or UMP $(1 \mathrm{mM})$ or no ligand added.

\section{Effect of $\mathrm{pH}$ on the rate of photoinactivation of the enzyme}

It was earlier reported (Westhead, 1965) that the rate of photooxidation of histidine in the presence of rose bengal was $\mathrm{pH}$ dependent with the unprotonated form being more susceptible to photooxidation. To examine the possibility whether the inactivation of the enzyme by rose bengal in the presence of light was due to the loss of a histidine residue, the rate of photoinactivation of the enzyme was studied at $\mathrm{pH} 6 \cdot 0,7 \cdot 0$ and $8 \cdot 0$. 
The $K_{\text {app }}$ value at these $\mathrm{pH}$ values was $0.015 \mathrm{~min}^{-1}$. As histidine has a $p^{K} a$ of 6-7 in most proteins (Tanford, 1962), this observation suggests that the loss of enzyme activity by photooxidation may probably be not due to the loss of a histidine residue. Attempts to demonstrate the presence of a reactive histidine by chemical modification of the enzyme were unsuccessful suggesting that this amino acid may not be essential for activity.

Spectral studies on the interaction of rose bengal with the enzyme

Effect of enzyme on the rose bengal absorption spectrum: Rose bengal showed an absorption maximum at $550 \mathrm{~nm}$ (figure 7) in $10 \mathrm{mM}$ potassium phosphate buffer, $\mathrm{pH}$ 7.6. Upon the addition of the enzyme, the absorption maximum of the dye showed a red shift of $7 \mathrm{~nm}$ in its absorption along with an increase in absorbance at all wavelengths (figure 7). The dye spectrum showed a similar red shift and an increase in absorbance when it was recorded in $50 \%$ ethanol (data not shown).

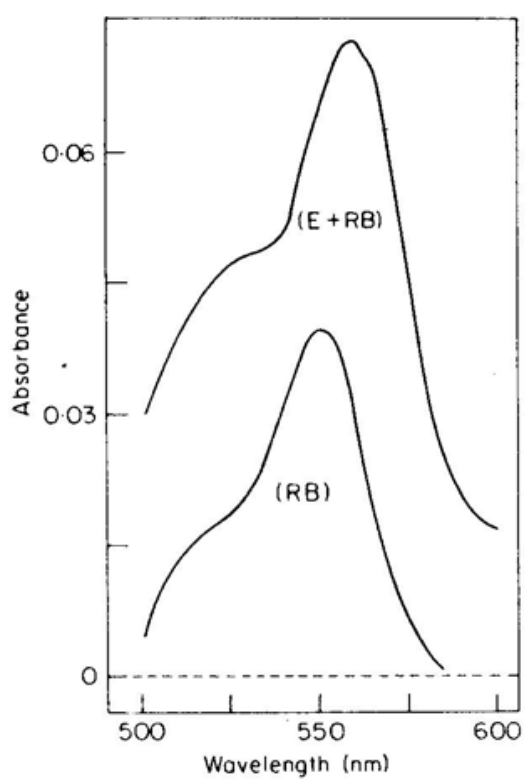

Figure 7. Effect of the addition of the enzyme on the absorption spectrum of the dye.

The absorption spectrum of rose bengal $(0.42 \mu \mathrm{M})$ was recorded in $10 \mathrm{mM}$ potassium phosphate buffer, pH 7.6 from 500 to $600 \mathrm{~nm}$. The spectrum of the dye $(0.42 \mu \mathrm{M})$ was again recorded under similar conditions in the presence of the enzyme $(2 \cdot 5 \mu \mathrm{M})$.

Difference spectra of the dye in the presence of the enzyme and the enzyme plus ligands: The difference spectrum of the dye $(450$ to $570 \mathrm{~nm})$ upon the addition of the enzyme is shown in figure 8 . The difference spectrum showed a peak around $565 \mathrm{~nm}$ and a trough at $540-550 \mathrm{~nm}$. When UMP $(2 \cdot 7 \mathrm{mM})$ was added to the reference cuvette containing the dye and to the sample cuvette containing the dye-enzyme complex, there was a perturbation of the difference spectrum (figure 8A). On the other hand, PALA $(200 \mu \mathrm{M})$ had no effect on the difference spectrum of the dye and the dye-enzyme complex (figure 8B). However, when U M P was added to the sample cuvette containing 


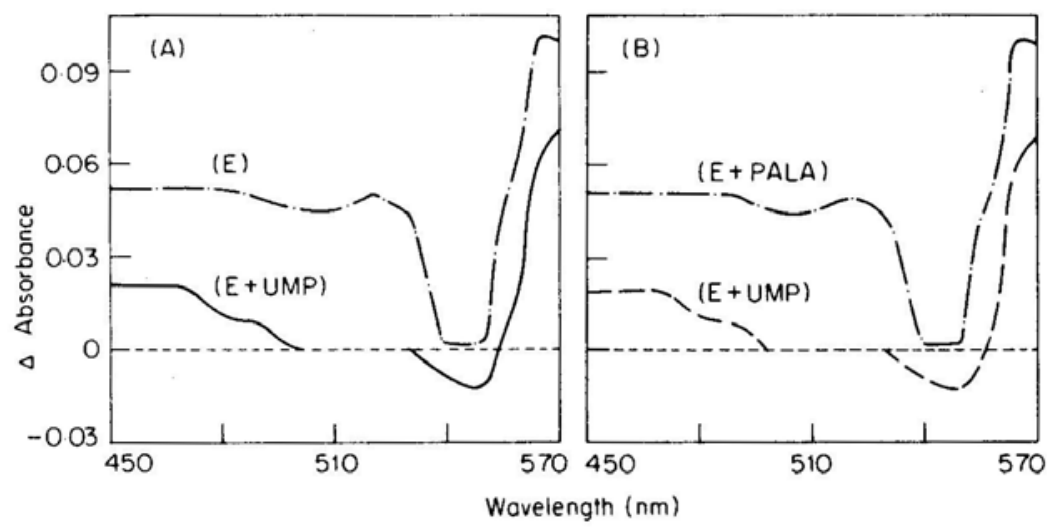

Figure 8. A. Diference spectrum of the dye in the presence of enzyme (E) and enzyme + UMP (E + UMP).

Rose bengal $(2 \cdot 1 \mu \mathrm{M})$ was taken in both the sample and reference cells in $10 \mathrm{mM}$ potassium phosphate buffer, $\mathrm{pH} 7 \cdot 6$ and the base line was recorded from 450 to $570 \mathrm{~nm}$, The sample cuvette was made up with dye $(2 \cdot 1 \mu \mathrm{M})$ and enzyme $(40 \mu \mathrm{g})$ in the same buffer and the difference spectrum was recorded. UMP $(2 \cdot 7 \mathrm{mM})$ was added to both the cells and the spectrum was again recorded.

B. Difference spectrum of the dye in the presence of (E + PALA) or (E + PALA + UMP). The difference spectrum of the dye $(2 \cdot 1 \mu \mathrm{M})$ was recorded after the addition of enzyme $(40 \mu \mathrm{g})$ as described above. PALA $(200 \mu \mathrm{M})$ was added to both the cells and the difference spectrum was re-recorded. UMP $(2.7 \mathrm{mM})$ was added to the reference cell containing the dye + PALA and to the sample cell containing the dye + enzyme + PALA and the difference spectrum was again recorded.

the dye-enzyme-PALA complex and to the reference cuvette containing the dye and PALA, the difference spectrum was perturbed in a manner similar to that observed in figure $8 \mathrm{~A}$. This result showed that only UMP, but not PALA could displace the dye from the enzyme.

\section{Electrophoretic behaviour of the enzyme in the presence of rose bengal}

The purified mung bean aspartate transcarbamylase exhibited multiple bands on PAGE when stained both for protein and activity. UMP converted this multiple band pattern on PAGE to a single band (Prasad and Appaji Rao, 1984). To further examine the similarities in the effects of rose bengal and UMP on the mung bean enzyme, it was subjected to PAGE in the presence of $15 \mu \mathrm{M}$ rose bengal. As seen in figure 1 (inset), the enzyme migrated as a single band in the presence of rose bengal as revealed by activity staining.

\section{Discussion}

The structure-function relationships of proteins have been probed by a variety of methods. The results presented in this paper demonstrate that simple kinetic measurements can be used to locate the allosteric site on mung bean aspartate transcarbamylase using the interaction of rose bengal as a convenient probe. The 
following experimental observations presented in the paper suggest that rose bengal was interacting at the UMP binding domain of the enzyme: (i) The inhibition patterns of the dye in the absence of light (figure 1) and of UMP (Prasad and Appaji Rao, 1984) were sigmoidal with $n_{H}$ value of $3 \cdot 2$ and $2 \cdot 2$, respectively, (ii) Rose bengal altered the electrophoretic behaviour of the enzyme, converting the multiple enzymatically active bands into a single band (figure 1, inset) in a manner similar to that by UMP (Prasad and Appaji Rao, 1984). (iii) The absorption spectrum of the dye was perturbed upon binding to the enzyme (figure 7). The red shift in the visible absorption spectrum of the dye and the increase in absorbance upon the addition of the enzyme suggested that the dye was probably binding in a hydrophobic region on the enzyme. Similar observations were made with the interaction of rose bengal with RNA polymerase $(\mathrm{Wu}$ and $\mathrm{Wu}$, 1973a). Additional evidence for the dye binding in a non-polar region on the enzyme was the observation that the dye spectrum showed a similar red shift and an increase in absorbance in $50 \%$ ethanol (data not shown). The dye difference spectrum was perturbed by UMP (figure 8A), but not by PALA (figure $8 \mathrm{~B}$ ) further suggesting that the dye was probably interacting at the UMP binding domain on the enzyme. (iv) Both the dye (figure 3) and UMP (Savithri et al., 1978a) acted as noncompetitive inhibitors of the enzyme when L-aspartate was the varied substrate. (v) Both rose bengal (figure 5) and UMP (Prasad and Appaji Rao, 1984) induced hysteresis in the enzyme which was abolished by preincubation with carbamyl phosphate. (vi) Finally, UMP protected the enzyme against photoinactivation in the presence of rose bengal (figure 6).

The interaction of rose bengal at the UMP binding domain might appear surprising as this dye does not bear any structural resemblence to nucleoside- mono, -di or triphosphate. However, it is pertinent to point out that Glazer (1970) has suggested that the binding of dyes to proteins occurs in regions overlapping the binding sites for substrates, coenzymes and prosthetic groups in preference to other regions on the protein surface. This preferential binding might reflect the special stereochemical features of the biospecific ligand binding sites and their hydrophobicity relative to other regions. / lthough, Cibacron Blue F3GA was originally believed to interact at the dinucleotide fold (Thompson et al., 1975; Thompson and Stellwagen, 1976; Stellwagen, 1977), extensive literature is now available to indicate that the dye might interact at other regions on some proteins (Steitz et al., 1916; Chambers and Dunlap, 1979; Ramesh and Appaji Rao, 1980). Rose bengal was shown to bind at the pyridine nucleotide binding sites in some dehydrogenases (Brand et al., 1967; Bond et al., 1970; Rippa et al., 1970). Interaction of rose bengal with RNA polymerase ( $\mathrm{Wu}$ and $\mathrm{Wu}$, $1973 \mathrm{a}, \mathrm{b})$ altered the catalytic properties of the enzyme markedly without binding to the nucleoside triphosphate or the DNA template binding sites. Thus, it is clear that a wide range of interactions of the dyes with proteins is possible.

An interesting suggestion that can be made from these studies is that in mung bean aspartate transcarbamylase the active and the allosteric sites are probably close to each other. The following arguments are compatible with these suggestions: (i) The dye which binds at the UMP binding domain caused inactivation of the enzyme in the presence of light (figure 5). This result suggested that the loss of the allosteric site had adverse effect on the catalytic activity of the enzyme. The enzyme was protected against photoinactivation both by UMP and PALA (figure 6). This result showed that blocking of either both the substrate sites or the allosteric site protected the enzyme. 
(ii) The allosteric and the active sites were distinct as suggested by the observation that the difference spectrum of the dye was perturbed by UMP, but not by PALA (figure 8)In the case of $E$. coli aspartate transcarbamylase, the regulatory site could be destroyed without affecting the catalytic activity (Gerhart, 1970) showing that the active site and allosteric site were spatially well separated. In the mung bean enzyme, it may be postulated that due to the nearness of both the sites, the destruction of the allosteric site adversely affected the active site. Mung bean enzyme is a hexamer with identical subunits (Prasad and Appaji Rao, 1983) unlike the E. coli enzyme which has separate catalytic and regulatory subunits (Gerhart, 1970). It could be argued that rose bengal has two binding sites, one for inhibition and the other for photoinactivation. But the nearly identical $K_{i}$ values of 9 and $10 \mu \mathrm{M}$ obtained from the inhibition (figure 3 ) and the inactivation (figure 6) argued against such a possibility. The observation of saturation kinetics in photoinactivation and the finding that pseudo first order kinetics were observed until the complete loss of activity suggested that rose bengal was interacting at a specific site on the enzyme. The inability to desensitize the enzyme without affecting the catalytic activity by other physical and chemical means (data not shown) also lend support to the hypothesis that in mung bean aspartate transcarbamylase, the active and the allosteric sites might be close to each other. The intermediary plateau region in carbamyl phosphate saturation upon preincubating the enzyme with the dye may be related to the ability of the dye to induce hysteresis (figure 4) and cause aggregation of the enzyme similar to UMP (Prasad and Appaji Rao, 1984). A partially purified enzyme preparation gave similar carbamyl phosphate saturation curves (Prasad and Appaji Rao, 1983) which was consistent with a slow association-dissociation of the enzyme (Kurganov et al., 1976).

All the above results are consistent with the hypothesis that the dye binds in a hydrophobic region on the enzyme which overlaps the regulatory site.

\section{References}

Bond, J. S., Francis, S. H. and Park, J. H. (1970) J. Biol. Chem., 245, 1041.

Brand, L., Gohlke, J. R. and Rao, D. S. (1967) Biochemistry, 6, 3510.

Chambers, B. B. and Dunlap, R. B. (1979) J. Biol Chem., 254, 6515.

Collins, K. D. and Stark, G. R. (1971) J. Biol Chem., 246, 6599.

Cleland, W. W. (1970) in The Enzymes (ed. P. D. Boyer) (New York: Academic Press) Vol 2, p. 1.

Coulson, A. F. W. and Yonetani, T. (1972) Eur. J. Biochem., 26, 125.

Davis, B. J. (1964) Ann. N.Y. Acad. Sci., 121, 404.

Gerhart, J. C. (1970) Curr. Top. Cell. Regul., 2, 275.

Glazer, A, N. (1970) Proc. Natl Acad. Sci. USA, 65, 1057.

Grayson, J. E. and Yon, R. J. (1978) Biochem. Soc. Trans., 6, 197.

Hoffee, P., Lai, C. Y., Pugh, E. L. and Horecker, B. L. (1967) Proc, Natl. Acad. Sci. USA, 57, 107.

Jacobsberg, L. B., Kantrowitz, E. R. and Lipscomb, W. N. (1975) J. Biol. Chem., 250, 9238.

Kamogawa, A. and Fukui, T. (1975) Biochim. Biophys. Acta, 403, 326.

Kurganov, B. I., Dorozko, A. I., Kagan, Z. S. and Yakovlev, V. A. (1976) J. Theor. Biol., 60, 271.

Lowry, O. H., Rosebrough, N. J., Farr, A. L. and Randall, R. J. (1951) J. Biol Chem., 193, 265.

Prasad, P. V. (1983) Regulatory Mechanism and Interactions at the Allosteric and Active Sites of Mung Bean

(Vigna radiata) Aspartate Transcarbamylase, Ph. D. Thesis, Indian Institute of Science, Bangalore.

Prasad, P. V. and Appaji Rao, N. (1984) J. Biosci., 6, 233.

Prescott, L. M. and Jones, M. E, (1969) Anal. Biochem., 32, 408. 
Ramesh, K. S. and Appaji Rao, N. (1980) Biochem. J., 187, 249.

Rao, G. S. J., Prasad, P. V. and Appaji Rao, N. (1982) Biochem. Int., 4, 503.

Rippa, M., Picco, C. and Pontremoli, S. (1970) J. Biol. Chem., 245, 4977.

Savithri, H. S., Vaidyanathan, C. S. and Appaji Rao, N. (1978a) Proc. Indian Acad. Sci., B87, 67.

Savithri, H. S., Vaidyanathan, C. S. and Appaji Rao, N. (1978b) Proc. Indian Acad. Sci., B87, 81.

Steitz, T. A., Fletterick, R. J., Anderson, W. F. and Anderson, C. M. (1976). J. Mol. Biol., 104,197.

Stellwagen, E. (1977) Acc. Chem. Res., 10, 92.

Tanford, C. (1962) Adv. Protein Chem., 17, 69.

Thompson, S. T. and Stellwagen, E. (1976) Proc. Natl. Acad. Sci. USA, 73, 361.

Thompson, S. T., Cass, K. H. and Stellwagen, E. (1975) Proc. Natl. Acad. Sci. USA, 73, 361.

Westhead, E. W. (1965) Biochemistry, 4, 2139.

Wu, C. W. and Wu, F. Y. H. (1973a) Biochemistry, 12, 4349.

Wu, F. Y. H. and Wu, C. W. (1973b) Biochemistry, 12, 4343. 